\title{
FAKTOR PENYEBAB DAN DAMPAK SERTA KEBIJAKANNYA TERHADAP PERMASALAHAN PENCEMARAN SAMPAH
}

\author{
Monalisa Rahman \\ Program Studi Pendidikan IPS Fakultas Keguruan dan Ilmu Pendidikan \\ Universitas Lambung Mangkurat \\ Banjarmasin \\ e-mail:2010128220010@mhs.ulm.ac.id
}

\begin{abstract}
Abstrak
Ancaman serius bagi Indonesia sekarang adalah satu diantaranya permasalahan tentang sampah, karena umumnya masyarakat sering membuang sampah tidak pada tempatnya yang bisa mengakibatkan pencemaran lingkungan hidup. Kemudian upaya pengelolaan sampah yang tidak efektif akan mengakibatkan permasalahan atau persoalan lingkungan maupun kesehatan manusia. Hasil penulisan artikel ini bertujuan untuk menganalisis dan mendeskripsikan atau menjelaskan faktor-faktor penyebab dan dampak yang disebabkan oleh tumpukan sampah serta mengenai kebijakannya terhadap mengurangi permasahan persampahan. Adapun penulisan artikel ini juga menggunakan metode pendekatan kualitatif yaitu dengan menelaah dan memahami isi buku-buku, dokumen, skripsi atau jurnal-jurnal ilmiah lainnya yang relevan dan mendukung untuk menggambarkan atau mendeskripsikan mengenai faktor pemicu dan pengaruh yang disebabkan dari permasalahan tertumpuknya sampah.
\end{abstract}

Kata Kunci: Permasalahan lingkungan, Pencemaran sampah

\section{PENDAHULUAN}

Permasalahan lingkungan ialah permasalahan alamiah, yaitu kejadian-kejadian atau fenomena-fenomena yang terjadi sebagai dari bagian dari jalannya proses alamiah. Proses alamiah ini terjadi dengan tidak adanya mengakibatkan dampak yang substansial untuk konstelasi lingkungan tersebut dan bisa pulih kembali lalu secara natural aratu yang disebut sebagai homeostasi. Tapi dewasa ini, persoalan dan permasalahan lingkungan tidak hanya disebut sebagai persoalan yang bersifat alami belaka, sebab masyarakat kadang kala menjadi penyumbang yang sangat substansial secara elastis bagi terjadinya fenomena kerusakan lingkungan. Kemampuan manusia hidup selalu berhubungan atau tidak pernah lepas dengan keberadaan lingkungan (Abbas \& Mutiani, 2018). Persoalan dan permasalahan lingkungan yang berkembang ini kebanyakan disebabkan oleh dari perbuatan manusia yaitu masalah yang kompleks dan lebih rumit dibandingkan dengan permasalahan lingkungan yang disebabkan oleh lingkungan itu sendiri atau yang terjadi secara alami. Masyarakat dengan beraneka ragam matra khususnya pada meningkatnya mobilitas pertumbuhan manusia, pola pikiran dan perkembangan unsur-unsur budaya, serta pemicu jalannya proses waktu yang mengonversi perilaku dan pemikiran masyarakat, ialah faktor pemicu yang lebih cocok dihubungkan dengan permasalahan lingkungan hidup semula permasalahan lingkungan yakni pendirian yang dilaksanakan dengan tidak melihat hasil dari akibat pembangunan atau pendirian sesuatu 
serta keseimbangan lingkungan yang akhirnya menyebabkan kehancuran, kerusakan, ketidakselarasan dan pencemaran lingkungan (Herlina, 2017: 2-3).

Pencemaran ialah suatu kondisi yang mana didalamnya ada suatu energi atau zat yang terantar ke suatu tempat atau lingkungan akibat aktivitas masyarakat atau jalannya proses alamiah dalam pemfokusan, sehingga mengakibatkan revolusi dalam kondisi yang substansial dan berdampak pada lingkungannya tidak berguna bagaikan semula, artinya dalam kesehatan manusia, keselamatan serta kesejahteraan manusia (Erwin, 2008: 36 dalam Herlina, 2017: 3).

Indonesia dewasa ini sering dan banyak mengalami persoalan dan permasalahan yang serius tentang kerusakan dan pencemaran lingkungan yang semakin meningkat. Masalahmasalah lingkungan ini yang cukup kompleks dan akan menjadi keharusan bertanggung jawab terhadap berkenaan mutu kehidupan generasi masa depan. Ketersediaan sumber daya alam dan lingkungan yang memadai disini sangat berperan penting dan mendukung dalam memenuhi kebutuhan manusia baik itu sosial ataupun ekonominya sehingga manusia mampu memenuhi kebutuhannya dalam berkegiatan (Abbas, Hadi \& Rajiani, 2018). Keberhasilan pembangunan dan mobilitas pertumbuhan manusia serta pertumbuhan ekonomi yang dilakukan dengan memanfaatkan sumber daya alam banyak mengakibatkan dampak negatif bagi lingkungan. Penggunaan pada SDA serta lingkungan yang berlebihan telah mengakibatkan semakin melemahnya mutu lingkungan hidup terutama SDA (sumber daya alam). Semarak rusaknya alam, seperti hancurnya sebagian besar hutan yang menjadi paruparu dunia, kerusakan ekosistem lautan, tanah longsor, serta permasalahan banjir yang merajalela terjadi dimana saja dan tentunya masih banyak permasalahan lingkungan lainnya. Diantaranya permasalahan mengenai sampah yang pasti ada didaerah mana saja dan yang paling sering dirasakan dampaknya seperti tertumpuknya sampah mengakibatkan bau yang semerbak dan yang fatal adalah bisa menyebabkan banjir (Nisa, 2020: 295). Dalam artikel ini akan lebih mendalam membahas mengenai penyebab dan dampak yang ditimbulkan dari menumpuknya sampah.

\section{METODE}

Metode atau teknik yang dipergunakan pada penyusunan jurnal atau artikel ini ialah teknik atau metode pendekatan kualitatif yaitu studi kepustakaan atau studi literatur yaitu dengan mencari, menelaah dan memahami isi buku-buku, dokumen, skripsi atau jurnal-jurnal ilmiah lainnya yang relevan dan mendukung untuk menggambarkan atau mendeskripsikan mengenai faktor pemicu dan akibat yang dihasilkan dari permasalahan tertumpuknya sampah serta kebijakannya terhadap permasalahan tersebut. Situs yang digunakan dalam penulisan 
artikel ini ialah seperti Google Scholar, dan data yang diperoleh ada 9 jurnal yang menggunakan kata kunci: (i) permasalahan, (ii) lingkungan dan (iii) sampah. Masing-masing dari 9 jurnal tersebut dibaca dengan cermat dari abstrak hingga kesimpulan, untuk memperoleh informasi berkaita dengan faktor pemicu dan akibat yang dihasilkan dari permasalahan tertumpuknya sampah serta kebijakannya terhadap permasalahan tersebut.

\section{PEMBAHASAN}

Sampah merupakan bahaya yang cukup serius untuk kehidupan masyarakat, sebab membuang atau menyisakan sampah tidak pada tempatnya bisa mengakibatkan pencemaran lingkungan. Masyarakat cenderung malas membuang sampah karena malas harus membuka tutup tempat sampah yang bau dan kotor. Selain itu juga, walaupun dengan sudah ada tersedia tempat atau tong sampah sesuai jenis sampahnya. Tapi sebagian masyarakat masih ada yang membuang atau menyisakan sampah sembarangan yang tidak sesuai dengan jenisnya. Tong sampah yang berisi penuh dan lama berada di situ terpaksa menunggu petugas kebersihan datang untuk diambilnya hingga sampah terlantar jadi tertumpuk. Jika tumpukan sampah itu semakin banyak itu tidak dibarengi dengan pengelolaan yang efektif maka dapat mengakibatkan berbagai persoalan dan permasalahan baik sosial maupun kesehatan.

Selain itu juga terkait pada meningkatnya volume sampah ialah ragam dan jenis, karakteristik serta spesifikasi sampah yang meningkat diimbangi oleh munculnya material yang akhinya memerlukankan sistem penanganan yang lebih baik dari yang semula, seperti sampah elektronik dan plastik, dan sisa lainnya yang dikelompokkan pada limbah khususnya B3 atau yang disebut limbah bahan berbahaya dan beracun yang pastinya memerlukan penanganan yang lebih ekslusif daripada dengan sampah domestik lain sebagainya. Oleh karenanya persoalan kesehatan dan kebersihan lingkungan ialah persoalan yang komprehensif yang harus dihadapi oleh belahan dunia, salah satunya Indonesia. Selain itu adanya ketidakselarasan mengenai sampah yang diciptakan dan pengelolaan sampah menjadi persoalan yang inklusif terutama diwilayah perkotaan yang ada di Indonesia (Kahfi, 2017: 14).

Hal ini terlihat bahwa persoalan lingkungan secara konvensional ditimbulkan dari beraneka situasi, baik itu yang bersifat natural (alam) ataupun sebab perbuatan serakah masyarakat atau manusia dan semua kegiatannya. Sampah ialah material yang disisakan atau terlantar dari cipta atau hasil kegiatan masyarakat ataupun alam yang telah unfungsional lagi sebab telah digunakan aspek atau manfaat eminennya. Hasil dari kegiatan masyarakat, sedikit banyaknya, tumpukan sampah selalu ada selagi manusia itu masih berkegiatan. Kegiatan 
yang dilaksanakan masyarakat (aktivitas industri) bukanlah aktivias alami sebab hasil kotoran manusia tidak tergolong kedalam kelompok sampah(Kahfi, 2017: 16).

Dari sisi lingkungan, sampah bisa mengakibatkan pencemaran atau gangguan terhadap lingkungan hidup. Dalam SNI (Standar Nasional Indonesia) pada tahun 2002, definisi sampah ialah limbah berkarakter padat yang mencakup material organik dan anorganik yang dianggap tak berdayaguna lagi dan harus dikelola supaya tak menjadi ancaman merusak lingkungan dan juga untuk melindungi dan memelihara investasi atau pembangunan (Kahfi, 2017: 16-17).

Berdasarkan beberapa definisi sampah, dapat disimpulkan, sampah ialah materil baik itu dari manusia ataupun nature yang tak digunakan lagi, tak diperlukan, tak memiliki value serta tak berharga yang akhirnya terlantar atau terbuang, yang merupakan materil yang bisa menganggu bahkan mengancam fungsi lingkungan.

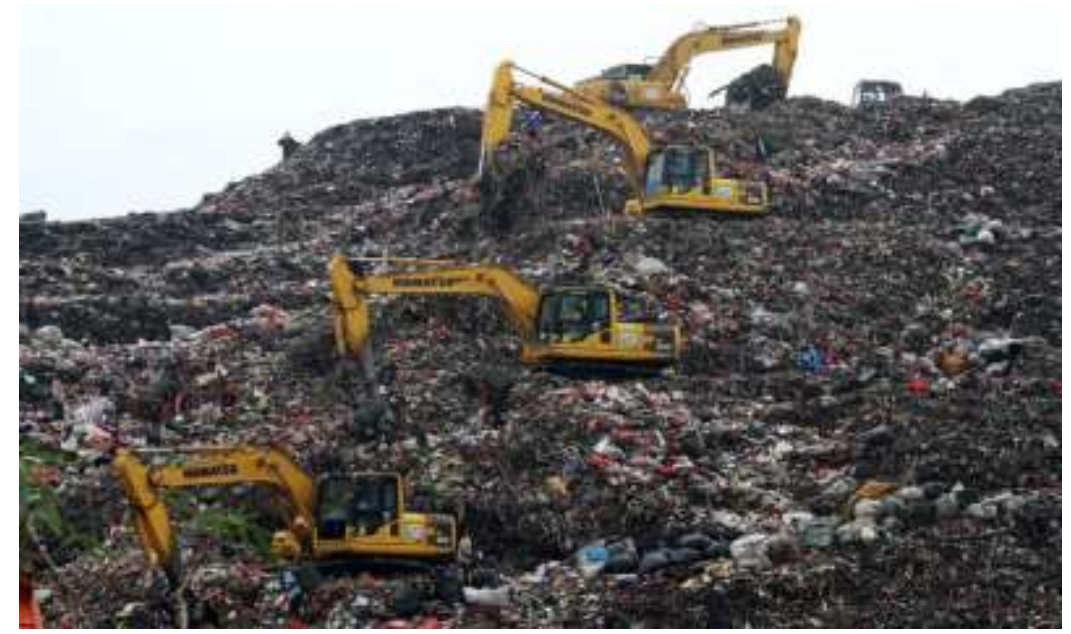

Gambar 1. Menumpuknya sampah.

Sumber: Nationalgeographic.grid.id

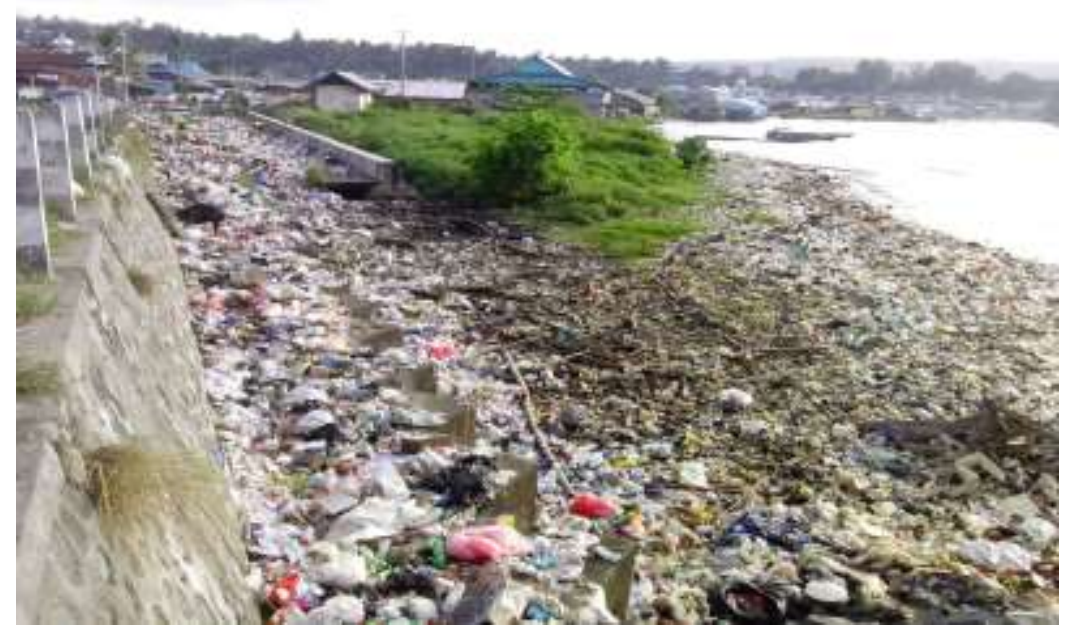

Gambar 2. Menumpuknya sampah di sekitar sungai.

Sumber: infostudikimia.com 
Permasalahan sampah menjadi serius sebab rumitnya persoalan yang ditemui dan petumbuhan mobilitas penduduk yang meningkat, hinggapenanganan sampah kerap diutamakan penyelesaiannya. Persoalan dimasyarakat terhadap pengelolaan sampah, kerap adanya sikap serta tatanan pola kehidupan masyarakat yang cenderung merujuk kepada meningkatnya cepatnya timbunan sampah yang mempersulit pihak pengelola kebersihan, terbatasnya alokasi essentials, fasilitas transportasi hingga pihak pengelola kebersihan tidak atau belum mampu menanggapi semua sampah yang diciptakan atau dihasilkan (Kahfi, 2017: 17).

Sampah diibaratkan sebagai suatu permasalahan. Adapun Sudrajat mengatakan bahwa sampah adalah suatu persoalan yang sangat penting terutama pada masyarakat yang tinggal di perkotaan, dan ini bisa terjadi diakibatkan oleh beberapa faktor yakni: (i) daya dampung TPS dan TPA yang terbatas dikarenakan jumlah sampah yang sangat banyak. (ii) lahan TPA yang lumayan kecil dan mengarah pada lain tujuan. (iii) teknologi penanganan pengelolaan sampah yang tidak ideal, dapat mengakibatkan meningkatnya kapasitas sampah yang membusuk. (iv) sampah yang lama berada di di TPA ataupun kompos tidak diangkat keluar dari TPA. (v) tidak efektifnya manajemen penanganan pengelolaan sampah. (vi) lemah atau kurangnya peranan dan dukungan atas kebijakan pemerintah (Kahfi, 2017: 18).

Tidak dapat dibenarkan, tingginya kapastitas sampah menjadi permasalahan besar yang ditemui oleh masyarakat yang tinggal di perkotaan sekaligus menjadi persoalan lingkungan hidup. Yang merupakan faktor-faktor penyebab menumpuknya sampah yakni sebagai berikut: (i) daya tampung TPA yang kurang dalam kapasitasnya dan diiringi dengan jumlah sampah yang sangat banyak. (ii) waktu untuk mengangkut sampah yang kurang efektif dikarenakan interval atau jarak TPA dengan pusat sampah yang relatif jauh (iii) fasilitas atau peralatan pemindahan sampah yang sedikit hingga terbatas maka tidak mampu mengangkat semua sampah. (iv) sisa sampah yang ada di TPS (Tempat Pembuangan Sampah) yang berkapasitas atau berpotensi menjadi gunungan sampah. (v) teknologi penanganan pengelolaan sampah yang tidak ideal, dapat mengakibatkan meningkatnya kapasitas sampah yang membusuk. (vi) adanya lingkungan yang tidak mempunyai lokasi pembuangan atau penampungan sampah, hingga kerap membuang sampah sembarangan. (vii) kurangnya pemasyarakatan atau sosialissi dan support pemerintah terkait penanganan pengelolaan sampah. (viii) sedikitnya kesadaran memanajemen diri dan edukasi tentang penanganan pengelolaan sampah dengan baik. Dan (ix) pemanajemenan sampah yang kurang tepat (Kahfi, 2017: 19). 
Adapun pengaruh jika tidak dikelolanya sampah dengan baik, menurut Suwerda, dampaknya ialah: (i) lingkungan menjadi jorok dan kotor atau tidak enak dilihat serta sampah menjadi asal munculnya berbagai macam penyakit. Timbunan sampah menjadi tempat yang bagus untuk mikroorganisme berkembang biak sehingga membahayakan kesehatan manusia, serta menjadi wadah bersarangnya tikus, bakteri, lalat dan lain sebagainya. (ii) pembakaran sampah bisa menyebabkan pencemaran udara sehingga menganggu kesehatan pernafasan manusia, serta menyebabkan terjadinya Global Warming. (iii) sisa sampah yang membusuk bisa menyebabkan bau yang tidak enak dan menjadi ancaman untuk kesehatan. Sisa cairan yang dikeluarkan bisa masuk dan menembus ke dalam tanah, dan bisa menyebabkan air tanah, sumur dan sungai tercemar. Dan (iv) sampah yang di lempar atau dibuang ke tubuh air ataupun ke sungai bisa mengakibatkan pendangkalan sungai, hingga bisa mengakibatkan terjadinya banjir (Kahfi, 2017: 19).

Inti persoalan sampah dikarenakan pertama terhubung erat terhadap kebiasaan manusia atau masyarakat yaitu kurang teratur atau disiplinnya serta kurangnya kesadaran masyarakat akan mengelola lingkungan.dan kedua berhubung, lemahnya kebijakan atau penyelesaian dari pemerintah terhadap pengelolaan lingkungan dan sampah, yang tampak pada peraturan ataupun sistem lembaga pemerintah menurut pendapat Nurhidayat dan Setyo Purwento (Kahfi, 2017: 20).

Kebijakan pengkoordinasian sampah saat ini cenderung belum menggunakan yang sesuai dengan teknik atau metode pengelolaan sampah yang berdasarkan dengan ilmu lingkungan sehingga berdampak kurang baik pada kesehatan lingkungan serta masyarakanya, dengan begitu pengelolaan lingkungan dan sampah mesti dilaksanakan dengan cara menyeluruh serta sistematis supaya bisa mengubah sikap masyarakatnya. Oleh karenanya diperlukannya kejelasan dan kepastian hukum mengenai kewenangan dan peranan Pemerintah, Pemda, serta tanggung jawab dunia usaha dan masyarakatnya terhadap pengelolaan sampah hingga bisa berproses dengan seimbang, efektif dan efisien (Kahfi, 2017: 20).

Berlandaskan UU. No 18 tahun 2008, pengelolaan sampah dapat dikatakan sebagai upaya serta aktivitas yang berututan, inklusif, dan berkelanjutan yang mencakup dari dua bagian yaitu penanganan dan pengurangan sampah. Didasarkan pada Undang-Undang itu juga didapati bahwa ada 3 kelompok yaitu; sampah rumah tangga, sampah sejenis rumah tangga dan sampah spesifiks yang dikelola (Kahfi, 2017: 20).

Jadi dapat disimpulkan bahwa pengelolaan sampah mencakup semua aktivitas yang berhubungan terkait mengendalikan munculnya sampah, pengiriman, pengumpulan serta alat 
pengangkut atau transportasi, proses pengolahan dan proses akhir atau pembuangan sampah dengan meninjau faktor kesehatan lingkungan, konservasi, teknologi ataupun ekonomi, keindahan serta faktor pemicu terkait lingkungan lainnya yang kuat hubungannya erhadap reaksi masyarakatnya.

Di Indonesia sendiri ditemui ada dua model teknik dalam pengelolaan sampah yakni tumpukan dan urugan. Model teknik ini biasanya dilaksanakan pada wilayah yang tak menyisakan kapasitas sampah jumlah yang banyak. Pada model teknik ini, sampah dibuang wilayah bercekukan dengan tidak adanya tindakan selanjutnya, hanya dibuang kemudian dibiarkan, model teknik ini ialah model pengelolaan sampah yang cukup sederhana dan bahkan bisa disebut dengan model yang mengdiskrepansi pandangan semula masyarakt tumum mengenai sampah.

Sementara model teknik pengelolaan sampah yang kedua ialah tumpukan yang dinilai lebih baik daripada model tekni pertama tadi, model teknik tumpukan ini difasiliasi dengan satuan unit penyaluran airuntuk buangan, leachatte (pengelolaan air untuk buangan) serta flare (pembakaran gas metan). Model teknik yang demikian sudah mencukupi kualifikasi lingkungan serta telah dipraktekkan banyak diwilayah perkotaan, tapi model teknik ini masih kurang utuh sesuai keadaan finansial serta keempatian dan rasa kepedulian pejabat atau pemimpin daerah sekitar pada kesehatan lingkungan serta masyarakatnya (Kahfi, 2017: 22).

Dalam menyelesaikan permasalahan sampah maka diharuskan melakukan pergeseran pendekaan, yaitu pendekaan ujung pipa menuju pada pendekatan sumber. Dengan demikian, sampah itu harus ditanggulangi mulai dari hulu sebelum sampah itu tadi sampai pada empat atau wadah pengolahan akhir sampah. Adapun prinsip mengenai pengelolaan sampah lain dalam pemanfaaannya, baik itu dari diberbagai daerah atau negara. Beberapa diantaranya yang paling biasa dilakukan, yaitu ialah: (i) $3 \mathrm{M}$ atau yang disebut dengan mengurangi penggunaan yang menghasilkan sampah, menggunakan lagi hasil sampah itu tadi setelah daya gunanya habis dan mendaur atau mengolah kembali sampah tersebut), yang mengkategorikan cara mengelola sampah sesuai kehendak pada sisi memanimalisir sampah. Tujuannya ialah guna mengambil arti atau keuntungan maksimal dari produk praktis dan guna memperoleh jumlah minimal limbah. (ii) memperpanjang Extended Producer Responsibility (tanggung jawab pencipta atau penghasil sampah. EPR merupakan suatu cara yang disusun guna mengiklankan penyatuan seluruh beban atau biaya yang behubungan pada produk atau hasil para produsen di semua perputaran produk itu kepada pasaran harga produk. Strategi ini bertujuan guna menetapkan akuntabilitas atas semua perputaran produk serta kemasannya yang dibawa kepasar. maka maksudnya perusahaan yang mengirim, 
mengolah serta menjual hasil atau produk dituntut guna beranggung jawab atas produk yang mereka hasilkan mulai pada manufaktur sampai akhir pada waktu pemanfaaannya. Dan (iii) konsep pengotor membayar, yaitu ialah konsep yang mana si pencemar itu membayar akibat atau pengaruh dari kegiatannya terhadap lingkungan. Berdasarkan pada pengelolaan sampah atau limbah, biasanya mengarah pada pihak penghasil atau pencipta sampah guna membayarnya sesuai dengan kapasitas kategori sampah yang dibuang (Kahfi, 2017: 22).

Prinsip 3M adalah prinsip yang diangkat dari prinsip 3R (reduce, recycle dan reuse), Sudrajat menyatakan prinsip ini ialah prinsip yang digunakan pada sebagian negara, tentang pemanajemenan pengelolaan sampah. Pengelolaan sampah di sebagian negara cenderung dimulai dari pengelolaan sampah di rumah tangga yakni memilah atau melakukan pemisahan sampah materil organik/ anorganik dengan memakai tempat tersendiri, atapun tempat yang dipakai ialah yang dapat dibuat kembali atau didaur ulang (Kahfi, 2017: 23).

Sedangkan yang di Indonesia, prinsip ini terdapat pada 5 UU No. 18 tahun 2008 Pasal 1 poin 5, kemudian ditegaskan lagi dalam Pasal 19, yaitu pengelolaan sampah meliputi aktivitas yakni penanganan dan pengurangan. Penanganan dalam pengurangan sampah ini didasarkan pada Pasal 20 atat 1 yaitu serangkaian aktivitas yang mencakup pembatasan guna meminimalisir timbunan sampah, mendaur kembali serta memanfaatkan lagi fungsi sampah yang telah habis dayagunanya. Sementara aktivitas solusi atau penyelesainan ditanganinya sampah mencakup aktivitas yaitu: (i) pemilihan atau pemisahan sampah berupa mengelompokkan dan memisahkan sampah sesuai dengan jenis kategori, volume, dan karakteristik sampah. (ii) mengumpulkan sampah berupa mengambil serta memindahkan sampah pada pangkal sampah menuju TPS sementara atau wadah membuat atau pengolahan sampah terpadu. (iii) mengangkut sampah berupa mengangkut pada pangkal sampah atau TPS ataupun pada TPS terpadu ke tempat proses akhir. (iv) mengolah sampah berupa mengubah karakter, struktur, serta volume sampah. Dan (v) proses terakhir dari pengelolaan sampah berupa mengembalikan sampah ataupun sisa hasil pengolahan yang menuju lingkungan secara sehat (Kahfi, 2017: 23).

didasarkan pada Undang-Undang tadi dapat dipahami bahwa cara pengelolaan yang dimaksud ialah pengelolaan sampah dengan mempraktekkan konsep 3R yaitu mencakup aktivitas pembatasan atau pengurangan timbunan sampah (reduce), memanfaatkan lagi sampah yang telah habis dayagunanya (reuse) dan proses pendauran atau pengolahan lagi sampah (recycle). Konsep 3R ini yang diinginkan bisa dan mampu menjadi solusi penyelesaian guna mengurangi persoalan tingginya volume timbunan sampah di TPS dan terbatasnya daya kapasitas TPA. Karena jika solusi dan penyelesaian penanganan persoalan 
tentang sampah yang dirasa masih kurang efektif bisa mengganggu elemen estetika perokotaan serta mengakibatkan pencemaran lingkungan hidup dan masalah kesehatan manusia.

\section{SIMPULAN}

Persoalan persampahan dan lingkungan sekarang ini tak luput dari berbagai sikap atau perilaku manusia sebagai pencipta atau penghasil sampah, selain itu juga tidak kuatnya peraturan mengenai permasalahan sampah dan lingkungan. Realitanya di suatu tempat lingkungan membuktikan tetap banyaknya anggota keluarga ataupun masyarakat yang tidak melaksanakan pemeliharaan lingkungan dan pengelolaan lingkungan yang dimulai di ranah rumah tangga dengan bagus, yaitu dari melakukan pemilahan serta pemisahan sampah, masalah penyimpanannya, dan juga membuang sampah pada tempat pembuangannya, selain itu tidak kuatnya peraturan dan sistem instansi diikuti memberikan peranan pada persoalan itu.

Dalam permasalahan lingkungan dan sampah ini, Jadi dirancanglah beragam pilihan, dengan pola-pola dalam mengelola sampah, yang ditekankan pada berubahnya pandangan umum masyarakat mengenai permasalahan sampah, seperti peranan setiap masyarakat dalam mengelola sampah. Selain itu juga diperkenalkan beragam model teknik mengelola dan menangani persoalan sampah yang dimulai diranah kecil yaitu rumah tangga sampai Tempat Pembuangan Akhir serta setelahnya diperkuat lagi dengan dokumen-dokemen perundangan hukum.

\section{DAFTAR PUSTAKA}

Deasy, A. (2017). Dampak Bencana Banjir Terhadap Keadaan Sosial dan Ekonomi masyarakat di Kecamatan Batu Benawa, Kabupaten Hulu Sungai Tengah, Kalimantan Selatan. JPG (Jurnal Pendidikan Geografi), 4(4), 42-52.

Deasy, A. (2020). Faktor Penyebab Terjadinya Kecelakaan Lalu Lintas di Daerah Rawan Kecelakaan Di Kecamatan Banjarmasin Tengah, Kota Banjarmasin. JPG (Jurnal Pendidikan Geografi), 2(3), 20-37.

Deasy, A. (2020). Studi Efektifitas Bank Sampah Sebagai Satu Pendekatan dalam Pengelolaan Sampah di Tingkat Sekolah Menengah Atas (SMA) di Banjarmasin. JPG (Jurnal Pendidikan Geografi), 3(5), 22-37.

Depan, P. P. K. Keadaan Lingkungan Hidup Di Jawa Tengan dan. 
Herlina, N. (2017). Permasalahan Lingkungan Hidup dan Penegakan Hukum Lingkungan di Indonesia. Jurnal Ilmiah Galuh Justisi, 3(2), 162-176.

Kahfi, A. (2017). Tinjauan terhadap Pengelolaan Sampah. Jurisprudentie: Jurusan Ilmu Hukum Fakultas Syariah dan Hukum, 4(1), 12-25.

Mulyadi, M., Siregar, F., \& Hasyim, I. A. (2019). Environmental Pollution and Damage Control Through Management Licensing at The Regional Level. $D E$ RECHTSSTAAT, 4(2), 93-104.

Noviana, S., Arisanty, D., \& Normelani, E. (2018). Pemanfaatan Air Sungai Kanal Tamban guna Kebutuhan Air Bersih Masyarakat di Kecamatan Tamban, Kabupaten Barito Kuala. JPG (Jurnal Pendidikan Geografi), 5(1).

Razikin, P., Kumalawati, R., \& Arisanty, D. (2017). Strategi Penanggulangan Bencana Banjir didasarkan Persepsi Masyarakat di Kecamatan Barabai, Kabupaten Hulu Sungai Tengah. JPG (Jurnal Pendidikan Geografi), 4(1). 